\title{
Penerapan Metode Tugas Guna Meningkatkan Hasil Belajar Tentang Dimensi Tiga di SMA Negeri 1 Bojong Gede, Kabupaten Bogor
}

\begin{abstract}
Author: Hastuti Nirmala ${ }^{1}$

Supardi U.S ${ }^{2}$ Hasbullah

Afiliation: Pascasarjana PMIPA, Universitas Indraprasta PGRI

Corresponding email hastutinirmala1978@gmail.com

Histori Naskah:

Submit: 2021-11-19 Accepted: 2021-11-19 Published: 2021-12-01

This is an Creative Commons License This work is licensed under a Creative Commons Attribution-NonCommercial 4.0 International License

Abstrak:

Penelitian ini bertujuan untuk mengukur besarnya peningkatan hasil belajar peserta didik tentang dimensi tiga setelah menggunakan metode pemberian tugas di Kelas XII IPA 1 SMA Negeri 1 Bojonggede Kabupaten Bogor Semester 1 Tahun Pelajaran 2021/2022. Metode penelitian ini adalah kualitatif dengan sampel sejumlah 42 siswa kelas XII IPA 1 Bojong Gede, Bogor. Pengumpulan data dilakukan secara tes uji kompetensi dan kuisioner wawancara. Hasil dan kesimpulan dari penelitian ini ialah hasil belajar mengalami peningkatan pada mata Pelajaran Matematika khususnya tentang dimensi tiga di kelas XII IPA 1 di SMA Negeri 1 Bojonggede Kabupaten Bogor sebelum menggunakan metode pemberian tugas mempunyai nilai rata-rata 60,71. Pada saat pembelajaran diubah menggunakan metode pemberian tugas, rata-rata hasil belajar peserta didik meningkat menjadi 70,36 pada siklus I dan 78,81 pada siklus II. Hal tersebut ditunjukkan dengan jumlah skor peserta didik 77 (61,11\%) dalam kerjasama dengan teman, sedangkan nilai keaktifan dalam kelompok skornya 79 atau $(62,69 \%)$. Kemudian peserta didik dalam aktif bertanya skornya 74 atau $(58,73 \%)$. Adapun peserta didik yang mengerjakan tugas guru skornya 96 atau (76,69\%), pada data mengenai aktifitas peserta didik pada siklus II menunjukkan bahwa jumlah skor peserta didik 119 (94,44\%) dalam kerjasama dengan teman, sedangkan nilai keaktifan dalam kelompok skornya 117 atau $(92,86 \%)$. Kemudian peserta didik dalam aktif bertanya skornya 107 atau $(84,92 \%)$. Adapun peserta didik yang mengerjakan tugas guru skornya 126 atau (100\%).
\end{abstract}

Kata kunci: Guru, Metode Pembelajaran, Peserta Didik, Tugas. 


\section{Pendahuluan}

Implementasi Undang-Undang Nomor 20 tahun 2003 tentang Sistem Pendidikan Nasional dijabarkan ke dalam sejumlah peraturan, di antaranya adalah Peraturan Pemerintah Nomor 19 Tahun 2005 tentang Standar Nasional Pendidikan sebagaimana telah beberapa kali diubah terakhir dengan Peraturan Pemerintah Nomor 13 Tahun 2015 tentang Perubahan Kedua Atas Peraturan Pemerintah Nomor 19 Tahun 2005 tentang Standar Nasional Pendidikan. Peraturan Pemerintah tersebut memberikan arahan tentang perlunya disusun dan dilaksanakan delapan standar nasional pendidikan, yaitu: standar isi, standar proses, standar kompetensi lulusan, standar pendidik dan tenaga kependidikan, standar sarana dan prasarana, standar pengelolaan, standar pembiayaan, dan standar penilaian pendidikan.

Standar Isi disesuaikan dengan substansi tujuan pendidikan nasional dalam domain sikap spiritual dan sikap sosial, pengetahuan, dan keterampilan. Oleh karena itu, Standar Isi dikembangkan untuk menentukan kriteria ruang lingkup dan tingkat kompetensi yang sesuai dengan kompetensi lulusan yang dirumuskan pada Standar Kompetensi Lulusan, yakni sikap, pengetahuan, dan keterampilan. Karakteristik, kesesuaian, kecukupan, keluasan, dan kedalaman materi ditentukan sesuai dengan karakteristik kompetensi beserta proses pemerolehan kompetensi tersebut. Ketiga kompetensi tersebut memiliki proses pemerolehan yang berbeda. Sikap dibentuk melalui aktivitas-aktivitas: menerima, menjalankan, menghargai, menghayati, dan mengamalkan. Pengetahuan dimiliki melalui aktivitas- aktivitas: mengetahui, memahami, menerapkan, menganalisis, mengevaluasi, dan mencipta. Keterampilan diperoleh melalui aktivitas-aktivitas: mengamati, menanya, mencoba, menalar, menyaji, dan mencipta. Karakteristik kompetensi beserta perbedaan proses pemerolehannya mempengaruhi

Berdasarkan Peraturan Pemerintah Nomor 19 Tahun 2005 tentang Standar Nasional Pendidikan ditetapkan bahwa Standar Isi adalah kriteria mengenai ruang lingkup materi dan tingkat kompetensi untuk mencapai kompetensi lulusan pada jenjang dan jenis pendidikan tertentu. Ruang lingkup materi dirumuskan berdasarkan kriteria muatan wajib yang ditetapkan sesuai ketentuan peraturan perundangundangan, konsep keilmuan, dan karakteristik satuan pendidikan dan program pendidikan. Selanjutnya, tingkat kompetensi dirumuskan berdasarkan kriteria tingkat perkembangan peserta didik, kualifikasi kompetensi Indonesia, dan penguasaan kompetensi yang berjenjang.

Adapun kondisi nyata di kelas XII IPA 1 SMA Negeri 1 Bojonggede Kabupaten Bogor khususnya tentang dimensi tiga. KKM yang telah ditentukan adalah 70 namun nilai peserta didik selalu rendah. Berdasarkan nilai harian yang telah dilaksanakan rata-rata memperoleh nilai 60,71. Dari 42 orang hanya 12 orang atau 28,57\% yang memiliki nilai di atas KKM yang telah ditentukan dan 30 peserta didik atau 71,43\% memiliki nilai di bawah KKM. Hal ini disebabkan guru dalam menjelaskankan dimensi tiga menggunakan metode ceramah, sedangkan peserta didik dijadikan sebagai obyek mendengar saja. Dalam KBM guru sangat aktif menjelaskan materi tersebut sedangkan peserta didik sebagai pendengar setia, bahkan ada peserta didik yang setiap saat minta izin ke kamar mandi dan ada peserta didik sampai mengantuk-ngantuk di kelas. Oleh karena itu peneliti akan mengubah cara mengajar dengan menggunakan metode pemberian tugas.

Program pembangunan manusia dan agenda UNDP 2030 berlabuh di universalisme pendekatan pembangunan manusia dengan menekankan peningkatan kebebasan bagi setiap manusia dan Agenda 2030 dengan berkonsentrasi untuk tidak meninggalkan siapa pun. Program pembangunan manusia dan Agenda UNDP memiliki fokus area yang sama untuk memberantas kemiskinan ekstrem, mengakhiri kelaparan, mengurangi ketidaksetaraan, memastikan kesetaraan gender, dan sebagainya pada. Program pembangunan manusia dan Agenda UNDP memiliki keberlanjutan sebagai inti prinsip. (Alhamidi, dkk, 2021).

Dari uraian di atas maka terdapat kesenjangan antara harapan kurikulum dan nilai yang diperoleh oleh peserta didik pada ulangan harian. Oleh karena itu peneliti berupaya akan merubah sistem pembelajaran khususnya tentang dimensi tiga dengan menggunakan metode pemberian tugas di kelas XII IPA 1 SMA Negeri 1 Bojonggede Kabupaten Bogor. 


\section{Studi Literatur}

Metode pemberian tugas dapat diartikan sebagai suatu format interaksi belajar mengajar yang ditandai dengan adanya satu tugas atau lebih tugas yang diberikan oleh guru, dimana penyelesaian tugastugas tersebut dapat dilakukan secara perseorangan atau secara kelompok sesuai dengan perintahnya. Sedangkan Supriatna, dkk (2007) mengemukakan bahwa metode penugasan (pemberian tugas) adalah suatu penyajian bahan pembelajaran dimana guru memberikan tugas tertentu agar peserta didik melakukan kegiatan belajar dan memberikan laporan sebagai hasil dari tugas yang dikerjakannya. Metode ini mengacu pada penerapan unsur-unsur "learning by doing". Menurut Nursid Sumaatmadja (2007), metode pembelajaran adalah cara yang fungsinya merupakan suatu alat untuk mencapai tujuan. Sedangkan menurut S. Hamid Hasan (Supriatna, 2007), metode pengajaran adalah suatu cara yang digunakan untuk memberikan kesempatan seluas-luasnya kepads peserta didik dalam belajar.

Dari dua pengertian di atas dapat disimpulkan bahwa metode pengajaran ialah suatu cara yang digunakan oleh guru dalam proses pembelajaran agar peserta didik dapat belajar untuk mencapai tujuan pembelajaran secara efektif dan optimal.

Dalam kegiatan belajar mengajar terdapat dua hal yang turut menentukan berhasil tidaknya suatu proses belajar mengajar, yaitu pengaturan proses belajar mengajar dan pengajaran itu sendiri. Kedua hal itu saling ketergantungan. Keberhasilan pengajaran dalam arti tercapainya tujuan-tujuan sangat bergantung pada pengaturan proses belajar mengajar. Proses belajar mengajar yang baik dapat menciptakan situasi yang memungkinkan anak belajar sehingga merupakan titik awal keberhasilan pengajaran.

Metode pembelajaran dapat menciptakan peserta didik belajar dengan baik dalam suasana yang wajar tanpa tekanan, dalam kondisi yang merangsang untuk belajar. Metode pembelajaran yang baik dapat memberikan bantuan dan bimbingan bagi peserta didik yang mendapat berbagai kesulitan belajar serta memberikan dorongan untuk memahami bahan pengajaran dalam berbagai kegiatan belajar, karena dalam kegiatan belajar peserta didik memerlukan sesuatu yang memungkinkan peserta didik berkomunikasi secara baik dengan guru, dengan teman, maupun dengan lingkungan sekitarnya. Kebutuhan akan bimbingan, bantuan dan perhatian guru bisa dilaksanakan dengan menggunakan metode pembelajaran yang efektif.

Metode pembelajaran yang digunakan oleh guru sangat beragam. Diantaranya metode ceramah, tanya jawab, diskusi, pemberian tugas, eksperimen, demonstrasi, kerja kelompok, proyek, dan sebagainya. Dalam menggunakan metode pembelajaran, guru harus pintar dalam memilih mana yang terbaik. Karena tidak semua metode sesuai dengan materi pelajaran yang diajarkan.

Hasil belajar merupakan hasil yang dicapai seseorang ketika mengerjakan tugas atau kegiatan tertentu. Prestasi akademik merupakan hasil belajar yang diperoleh peserta didik dari kegiatan pembelajaran di sekolah yang bersifat kognitif, afektif, dan psikomotorik yang dapat ditentukan melalui pengukuran dan penilaian.

Hal ini dapat diperkuat dari pendapat Tu'u (2004: 75) yang mengemukakan bahwa "Hasil belajar adalah penguasaan pengetahuan atau keterampilan yang dikembangkan oleh mata pelajaran, lazimnya ditunjukkan dengan nilai tes atau angka nilai yang diberikan oleh guru”.

Dalam arti luas mencakup pengetahuan, pemahaman, keterampilan, sikap dan sebagainya. Setiap perilaku ada yang tampak atau dapat diamati, dan ada pula yang tidak dapat diamati.

Menurut Dimyati dan Mudjiono (dalam Muakhirin, 2014), belajar adalah "Suatu perilaku pada saat orang belajar, maka responnya menjadi lebih baik. Sebaliknya, bila ia tidak belajar maka responnya menurun". Hal ini dapat diidentifikasi bahkan dapat diukur dari penampilan. Penampilan ini dapat berupa kemampuan menjelaskan, menyebutkan sesuatu atau melakukan suatu perbuatan.

Jadi, dari pendapat tersebut dapat diidentifikasikan hasil belajar melalui penampilan. Dimyati dan Mudjiono (dalam Muakhirin, 2014) mengatakan hasil belajar adalah "Penguasaan pengetahuan atau keterampilan yang dikembangkan oleh mata pelajaran, lazimnya ditunjukkan dengan nilai tes atau angka nilai yang diberikan oleh guru". 
Menurut Ali (dalam Yulianti, Iwan, Saeful, 2018) yang dimaksud dengan peserta didik yang memiliki hasil belajar baik adalah "Peserta didik setelah melaksanakan proses pembelajaran memiliki kemampuan untuk menganalisis masalah, menarik kesimpulan, menyusun gagasan secara konseptual, melukiskan suatu proses, menguraikan hubungan sebab akibat dan mendiskusikan suatu masalah

\section{Metode Penelitian}

Penelitian ini dilaksanakan di kelas XII IPA 1 SMA Negeri 1 Bojonggede Kabupaten Bogor. Untuk mendapatkan data yang diperlukan oleh penulis, digunakan Tes Uji Kompetensi dan Lembar observasi/wawancara. Prosedur penelitian ini berbentuk tindakan kelas yang merupakan proses pengkajian melalui sistem yang berdaur ulang dari berbagai kegiatan pembelajaran berupa perencanaan, pelaksanaan, pengamatan, dan refleksi (Lewin dalam Siti Peni Lestari, 2020). Pada penelitian tindakan kelas ini, digunakan analisis deskripsi kualitatif dengan teknik analisis data berupa penilaian evaluasi dan penilaian ketuntasan sederhana secara perhitungan statistik yang sederhana.

\section{Hasil}

Sebelum melakukan tindakan dalam penelitian, peneliti melakukan observasi awal di kelas. Hasil observasi menunjukkan bahwa ketika guru mengajar tentang dimensi tiga nilai rata- rata-rata memperoleh nilai 60,71. Dari 42 orang hanya 12 orang atau 28,57\% yang memiliki nilai di atas KKM yang telah ditentukan dan 30 peserta didik atau 71,43\% yang belum mencapai KKM. Sedangkan KKM yang telah ditentukan adalah 70 .

\section{Deskripsi Tindakan Siklus I}

\section{Perencanaan Tindakan}

Sebelum menyusun rencana pembelajaran, peneliti melakukan identifikasi masalah berdasarkan refleksi pada siklus I dan merencanakan langkah-langkah yang akan dilaksanakan pada siklus II. Setelah peneliti mengetahui masalah dan langkah-langkah yang akan digunakan pada tindakan di siklus II, peneliti kemudian membuat Rencana Pelaksanaan Pembelajaran (RPP). Menentukan pokok bahasan yang akan dijadikan materi bahasan pada penelitian. Mengembangkan Rencana Pelaksanaan Pembelajaran (RPP). Mengembangkan format evaluasi. Mengembangkan format observasi pembelajaran. 


\section{Pelaksanaan Tindakan}

Pelaksanaan tindakan pada siklus II dilaksanakan dalam dua kali pertemuan yaitu Pelaksanaan pembelajaran pada pertemuan pertama (peneliti terlebih dahulu meneliti tingkat kesiapan peserta didik, mengecek absensi peserta didik serta mengkondisikan kelas agar pembelajaran dapat terlaksana, Melakukan apersepsi dengan tanya jawab tentang dimensi tiga, selanjutnya peneliti menjelaskan materi secara singkat dengan diselingi tanya jawab dengan peserta didik tentang dimensi tiga, peneliti menampilkan contoh-contoh dimensi tiga, peserta didik diminta menanggapinya, beberapa peserta didik diminta mendapatnya tentang dimensi tiganya, peneliti menutup pelajaran dengan membimbing peseta didik melakukan diskusi secara klasikal untuk menarik kesimpulan dari materi yang telah dipelajari. Dengan kesempatan ini peserta didik diberi kesempatan untuk menanyakan hal yang belum jelas dari materi yang telah dipelajari).

Pelaksanaan pembelajaran pada pertemuan kedua (Peneliti terlebih dahulu meneliti tingkat kesiapan peserta didik, mengecek absensi serta mengkondisikan kelas agar pembelajaran dapat berlangsung secara kondusif, melakukan apersepsi dengan tanya jawab tentang dimensi tiga, Selanjutnya peneliti menjelaskan materi secara singkat dengan diselingi tanya jawab, Peneliti meminta beberapa peserta didik maju ke depan kelas untuk menampilkan contoh latihan soal jarak titik ke titik garis maupun bidang, Peneliti membagikan LKS tentang dimensi tiga, Peserta didik mendiskusikannya di kelompok yang telah dibentuk, Peneliti meminta beberapa peserta didik maju ke depan kelas untuk menyampaikan hasil pekerjaannya, Peneliti menutup pelajaran dengan membimbing peserta didik melakukan diskusi secara klasikal untuk menarik kesimpulan dari materi yang telah dipelajari. Kemudian peserta didik diberi kesempatan untuk menanyakan hal yang belum jelas dari materi yang telah dipelajari, Peneliti melakukan uji kompetensi berupa tes tertulis.

\section{Observasi}

Pada siklus II ini guru telah melakukan perbaikan-perbaikan. Perbaikan dalam KBM tersebut yaitu guru lebih memotivasi peserta didik, sehingga peserta didik lebih bersemangat dalam mengikuti KBM. Dengan semangat yang lebih tinggi, maka pembelajaran dapat berjalan lebih baik. Selain memotivasi peserta didik, guru juga memberikan lebih banyak kesempatan kepada peserta didik untuk menanyakan hal-hal yang belum jelas. 
Jika digambarkan dalam bentuk grafik, maka data keaktifan peserta didik pada siklus II tersaji pada gambar 1 berikut:

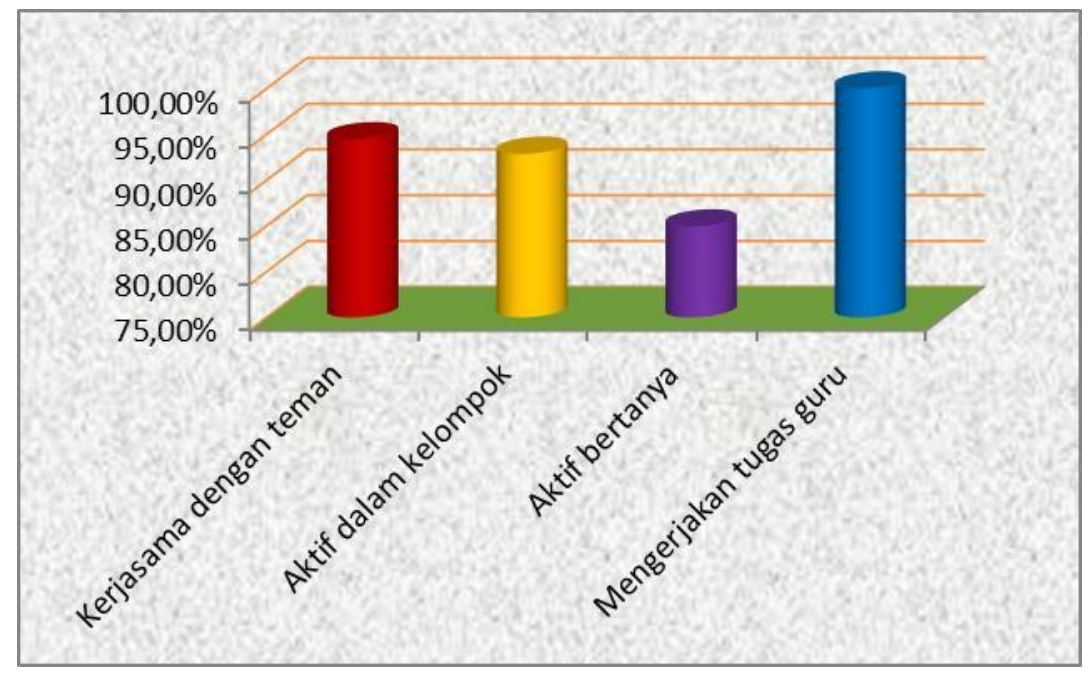

Gambar 1. Grafik Keaktifan Peserta Didik Pada Siklus II

Data mengenai aktifitas peserta didik pada siklus II menunjukkan bahwa jumlah skor peserta didik $119(94,44 \%)$ dalam kerjasama dengan teman, sedangkan nilai keaktifan dalam kelompok skornya 117 atau $(92,86 \%)$. Kemudian peserta didik dalam aktif bertanya skornya 107 atau (84,92\%). Adapun peserta didik yang mengerjakan tugas guru skornya 126 atau (100\%)

Jika digambarkan dalam bentuk grafik, maka data aktivitas guru pada siklus II tersaji pada grafik 4.6 :

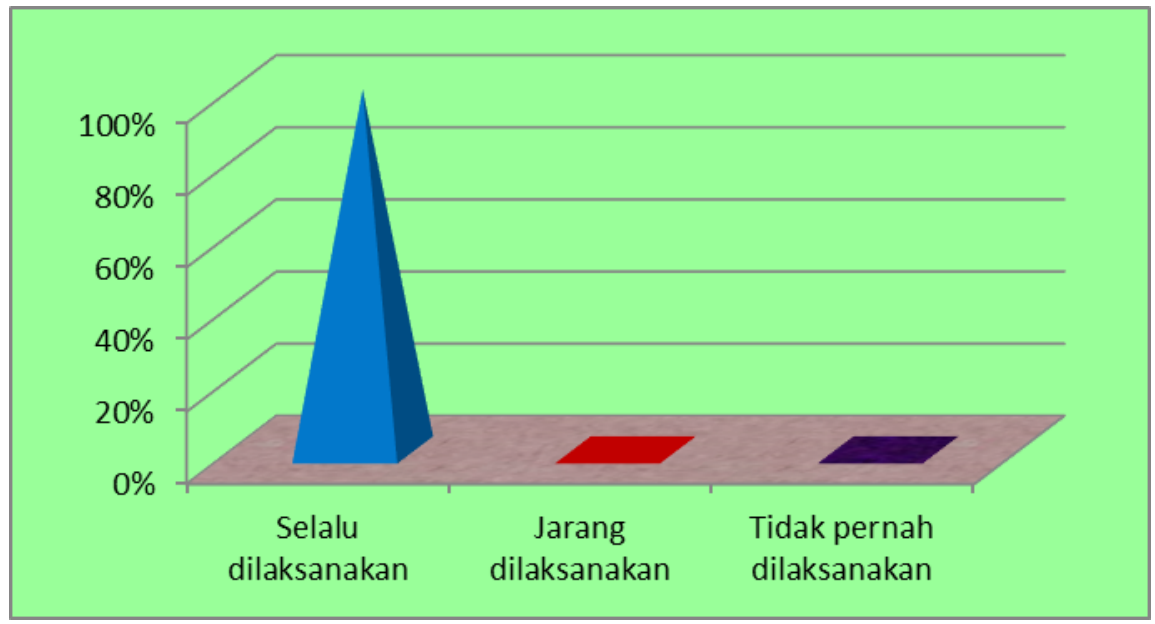

Gambar 2. Grafik Hasil Pengamatan Aktivitas Guru Pada Siklus II 


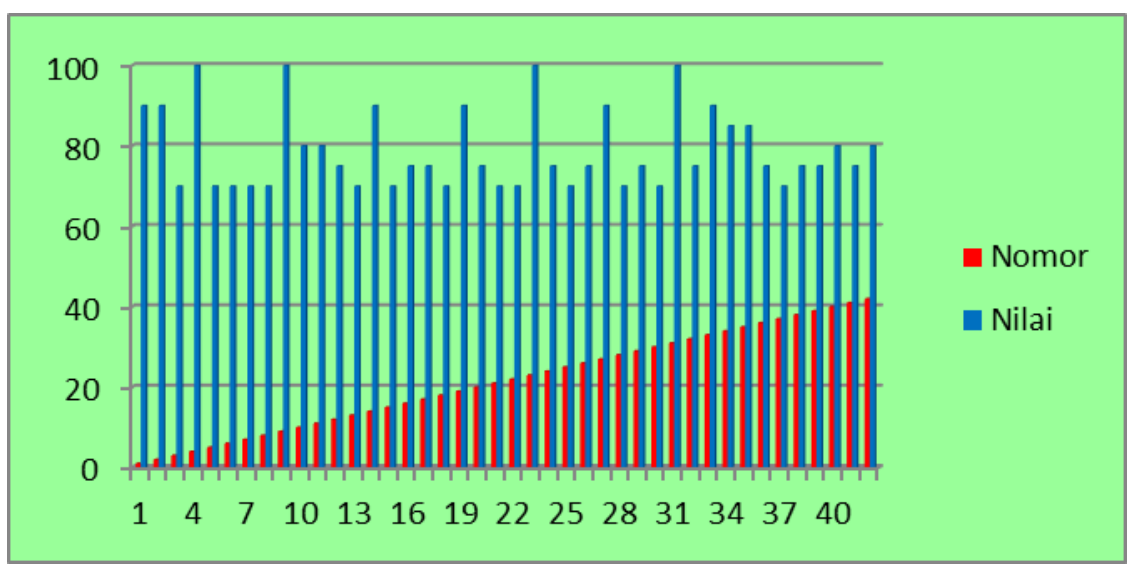

Gambar 3. Grafik Hasil Belajar Peserta Didik Pada Siklus II

Berdasarkan gambar 2 dan gambar 3, terlihat bahwa rata-rata nilai peserta didik 78,81 dengan nilai tertinggi 100 dan nilai terendah 70. Peserta didik yang hasil belajarnya di atas KKM ada 42 orang atau $100 \%$ dan di bawah KKM tidak ada atau 0\% dari nilai KKM yang ditetapkan yaitu 70. Hal ini memberikan gambaran bahwa ada peningkatan hasil belajar peserta didik dari siklus I ke siklus II.

Refleksi

Dari gambar 2 dan gambar 3, dapat diinformasikan bahwa hampir seluruhnya peserta didik menyukai pembelajaran dengan metode pemberian tugas dengan bukti rata-rata nilai 78,81. Kemudian nilai di atas KKM ada 42 orang (100\%) sedangkan yang di bawah KKM tidak ada (0\%) dari KKM yang telah ditentukan yaitu 70 sedangkan nilai terendah adalah 70 dan nilai tertinggi 100. Seluruh peserta didik (42 orang) dalam materi dimensi tiga sudah tuntas. Data mengenai aktifitas peserta didik pada siklus II menunjukkan bahwa jumlah skor peserta didik 119 (94,44\%) dalam kerjasama dengan teman, sedangkan nilai keaktifan dalam kelompok skornya 117 atau (92,86\%). Kemudian peserta didik dalam aktif bertanya skornya 107 atau $(84,92 \%)$. Adapun peserta didik yang mengerjakan tugas guru skornya 126 atau (100\%)

Kemudian aktivitas guru adalah $100 \%$ guru telah melaksanakan urutan pembelajaran yang telah ditulis di RPP. Hal ini dikarenakan peserta didik merasa tertarik dan termotivasi dalam KBM yang menggunakan metode pemberian tugas

\section{Pembahasan}

Dari hasil pembelajaran menggunakan metode pemberian tugas dan jawaban soal-soal evaluasi yang diberikan, kemudian peneliti menggunakan jawaban-jawaban tersebut untuk mengetahui apakah pembelajaran dimensi tiga menggunakan metode pemberian tugas tersebut dapat meningkatkan hasil belajar peserta didik kelas XII IPA 1 SMA Negeri 1 Bojonggede Kabupaten Bogor. Berikut ini adalah data yang diperoleh dari hasil pra siklus, siklus I, dan siklus II.

Tabel 1. Rekapitulasi Nilai Pra Siklus, Siklus I, dan Siklus II

\begin{tabular}{ccccc}
\hline No. & Nama Peserta didik & Pra Siklus & Siklus I & Siklus II \\
\hline 1 & Abdul Sattar & 75 & 80 & 90 \\
\hline 2 & Alam Nuramali & 75 & 80 & 90 \\
\hline 3 & Aldi Sopyan & 50 & 60 & 70 \\
\hline 4 & Anisa Khansa Putri & 80 & 90 & 100 \\
\hline 5 & Aulia Rifqi & 55 & 65 & 70 \\
\hline
\end{tabular}


Edu Cendikia: Jurnal Ilmiah Kependidikan

Volume: 1 | Nomor 3 | Desember 2021 | E-ISSN: 2798-365X | DOI: 10.47709/educendikia.v1i3.1187

\begin{tabular}{|c|c|c|c|c|}
\hline No. & Nama Peserta didik & Pra Siklus & Siklus I & Siklus II \\
\hline 6 & Azizah Mar'atussholikhah & 50 & 60 & 70 \\
\hline 7 & Dhonan Dhaifullah & 50 & 60 & 70 \\
\hline 8 & Dimas Saputra & 55 & 65 & 70 \\
\hline 9 & Eka Lestari & 80 & 90 & 100 \\
\hline 10 & Finalia Prawita & 55 & 70 & 80 \\
\hline 11 & Fira Putri Yanda & 55 & 70 & 80 \\
\hline 12 & Firdha Aulia & 60 & 70 & 75 \\
\hline 13 & Friska Aristia & 50 & 60 & 70 \\
\hline 14 & Hendra Mulyana & 75 & 80 & 90 \\
\hline 15 & Humaira Qotrunada Lewi & 50 & 60 & 70 \\
\hline 16 & Intan Luthfia & 55 & 65 & 75 \\
\hline 17 & Irsyad Kamal & 55 & 65 & 75 \\
\hline 18 & Izzah Fitriani & 50 & 60 & 70 \\
\hline 19 & Josita Qurratu Aini & 75 & 80 & 90 \\
\hline 20 & Khori Lukiyana & 55 & 70 & 75 \\
\hline 21 & Muhamad Figor & 50 & 60 & 70 \\
\hline 22 & Mohamad Viqi Azriel & 50 & 60 & 70 \\
\hline 23 & Muhammad Farhan & 80 & 90 & 100 \\
\hline 24 & Muhammad Husain Toekan & 55 & 65 & 75 \\
\hline 25 & Nabila Fazia Rahma & 50 & 60 & 70 \\
\hline 26 & Nanda Choirunnisa & 55 & 65 & 75 \\
\hline 27 & Noor Zadhira Aldra Khaeranti & 75 & 80 & 90 \\
\hline 28 & Nur Kholifah & 50 & 60 & 70 \\
\hline 29 & Pratama Meilandanau & 55 & 65 & 75 \\
\hline 30 & Pusparini & 55 & 65 & 70 \\
\hline 31 & Putri Ramadhini & 80 & 90 & 100 \\
\hline 32 & Rafli Armanda & 55 & 65 & 75 \\
\hline 33 & Ramdani Farhan & 75 & 80 & 90 \\
\hline 34 & Raul Islamy M & 75 & 80 & 85 \\
\hline 35 & Reiga Ananda Baja & 75 & 80 & 85 \\
\hline 36 & Rikard Andika & 60 & 70 & 75 \\
\hline 37 & Sherly Atha Kusuma & 55 & 65 & 70 \\
\hline 38 & Sintya Nur Vitasari & 50 & 70 & 75 \\
\hline 39 & Syafira Firdani & 60 & 70 & 75 \\
\hline 40 & Tasya Amalia Putri & 65 & 75 & 80 \\
\hline 41 & Kristina Herawati & 55 & 65 & 75 \\
\hline \multirow[t]{4}{*}{42} & Muhamad Febriyansyah & 65 & 75 & 80 \\
\hline & Rata-rata & 60,71 & 70,36 & 78,81 \\
\hline & Nilai Terendah & 50 & 60 & 70 \\
\hline & Nilai Tertinggi & 80 & 90 & 100 \\
\hline
\end{tabular}


Edu Cendikia: Jurnal Ilmiah Kependidikan

Volume: 1 | Nomor 3 | Desember 2021 | E-ISSN: 2798-365X | DOI: 10.47709/educendikia.v1i3.1187

\begin{tabular}{|c|c|c|c|c|}
\hline No. & Nama Peserta didik & Pra Siklus & Siklus I & Siklus II \\
\hline \multicolumn{2}{|c|}{ Jumlah Peserta Didik yang Sudah Tuntas } & 12 & 23 & 42 \\
\hline \multicolumn{2}{|c|}{ Jumlah Peserta Didik yang Belum Tuntas } & 30 & 19 & 0 \\
\hline \multicolumn{2}{|c|}{ Prosentase Ketuntasan } & $28,57 \%$ & $54,76 \%$ & $100 \%$ \\
\hline
\end{tabular}

Berdasarkan hasil penelitian selama dua siklus yang bertujuan untuk meningkatkan hasil belajar peserta didik pada mata Pelajaran Matematika tentang dimensi tiga. Terlihat pada pelaksanaan siklus I dan II telah menunjukkan peningkatan pada proses pembelajaran. Dengan metode pemberian tugas, interaksi peserta didik dan guru di awal pelajaran diawali oleh guru dengan memberikan tugas membuat laporan keuangan perusahan jasa secara kelompok, hal tersebut dimaksudkan agar peserta didik dapat belajar bekerjasama dengan temannya. Kemudian guru mengarahkan dan menjelaskan bagaimana peserta didik berdiskusi dengan baik. Saat proses pembelajaran berlangsung, guru mengelola kelas secara interaktif, membimbing peserta didik, dan memotivasi peserta didik untuk aktif berperan dalam kegiatan pembelajaran. Pada akhir pelajaran, guru bersama peserta didik menyimpulkan pelajaran yang telah dilaksanakan. Kemudian guru mengevaluasi peserta didik dengan memberikan soal-soal yang relevan dengan konsep. Berdasarkan hal tersebut, dapat disimpulkan bahwa telah ada peningkatan aktivitas peserta didik dalam pembelajaran mata Pelajaran Matematika. Hal ini dapat dilihat dari peningkatan ratarata nilai hasil belajar dari pra siklus, siklus I, dan siklus II yang tersaji pada gambar 4.

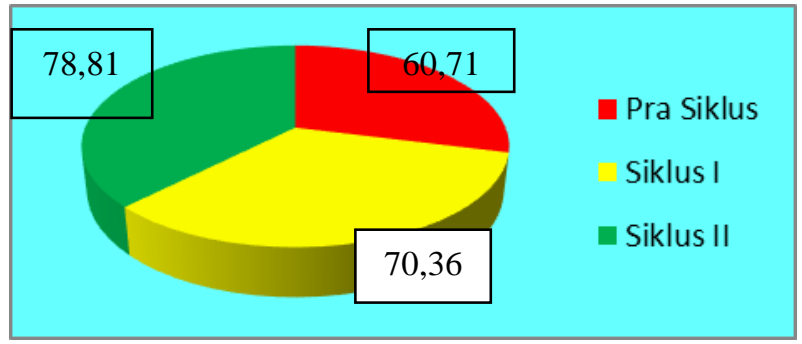

\section{Gambar 4 Grafik Peningkatan Rata-Rata Nilai Peserta Didik Tiap Siklus}

Peningkatan rata-rata nilai peserta didik juga ditunjang oleh peningkatan nilai terendah dan nilai tertinggi peserta didik setiap siklus seperti yang tergambar pada gambar 5, sebagai berikut

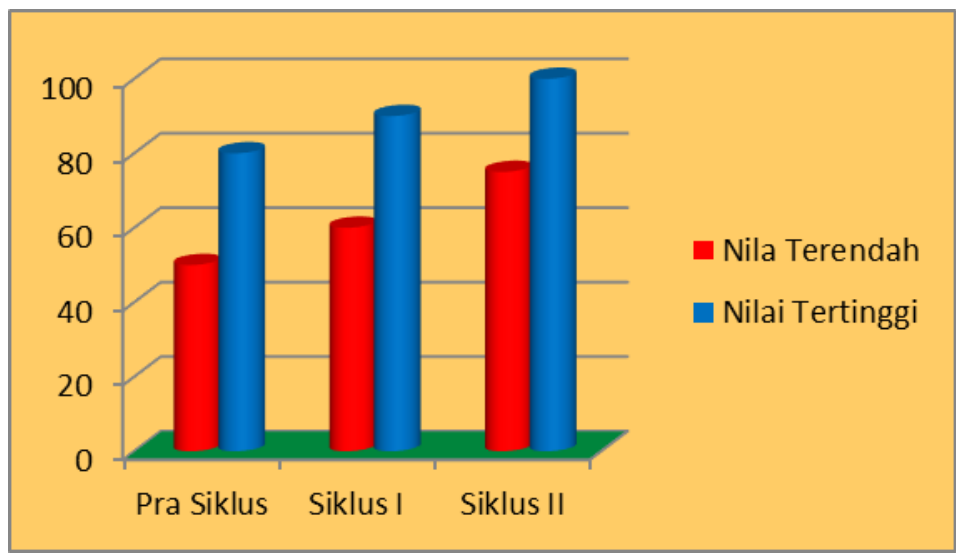

Gambar 5. Grafik Peningkatan Nilai Terendah dan Tertinggi Tiap Siklus 
Dari gambar 5, diperoleh bahwa nilai terendah pada pra siklus adalah 50 kemudian meningkat menjadi 60 pada siklus I dan meningkat lagi menjadi 70 pada siklus II. Selanjutnya nilai tertinggi pada pra siklus adalah 80 kemudian meningkat menjadi 90 pada siklus I dan meningkat lagi menjadi 100 pada siklus II. Hal ini membuktikan bahwa metode pemberian tugas cocok untuk diterapkan pada mata Pelajaran Matematika tentang dimensi tiga. Selain peningkatan rata-rata nilai peserta didik, penerapan metode pemberian tugas juga dapat meningkatkan persentase ketuntasan belajar peserta didik seperti yang tersaji pada gambar 3 .

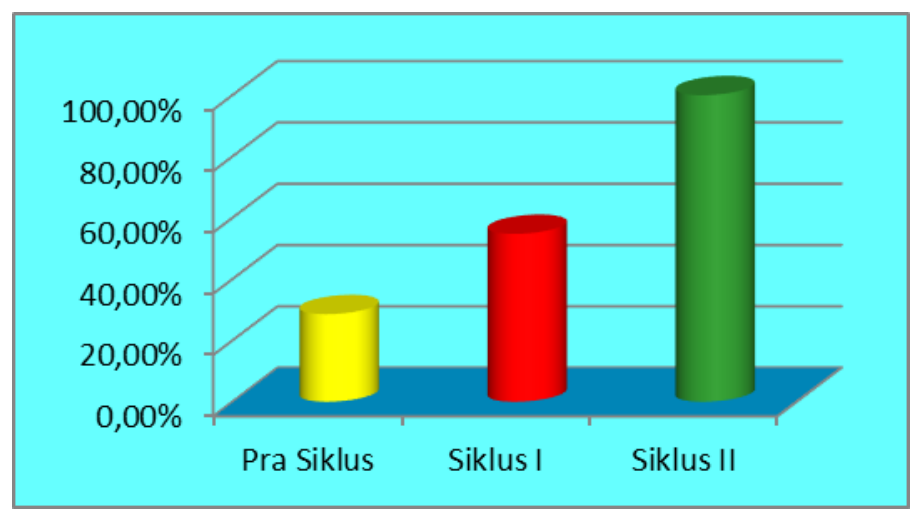

\section{Gambar 6. Grafik Peningkatan Ketuntasan Belajar Peserta Didik Tiap Siklus}

Dari gambar 6, diperoleh bahwa pada pra siklus hanya $28,57 \% \%$ atau 12 peserta didik yang nilainya di atas KKM yang ditetapkan, kemudian pada siklus I meningkat menjadi 54,76\% atau 23 peserta didik yang nilainya di atas KKM selanjutnya pada siklus II menjadi 100\% atau 42 peserta didik yang nilainya di atas KKM .

Data mengenai aktifitas peserta didik pada siklus I menunjukkan bahwa jumlah skor peserta didik $77(61,11 \%)$ dalam kerjasama dengan teman, sedangkan nilai keaktifan dalam kelompok skornya 79 atau $(62,69 \%)$. Kemudian peserta didik dalam aktif bertanya skornya 74 atau $(58,73 \%)$. Adapun peserta didik yang mengerjakan tugas guru skornya 96 atau (76,69\%), pada data mengenai aktifitas peserta didik pada siklus II menunjukkan bahwa jumlah skor peserta didik $119(94,44 \%)$ dalam kerjasama dengan teman, sedangkan nilai keaktifan dalam kelompok skornya 117 atau $(92,86 \%)$. Kemudian peserta didik dalam aktif bertanya skornya 107 atau $(84,92 \%)$. Adapun peserta didik yang mengerjakan tugas guru skornya 126 atau $(100 \%)$

Dengan banyaknya peserta didik yang aktif pada saat pembelajaran menunjukkan bahwa guru saat menerapkan materi dengan metode pemberian tugas sudah berhasil melibatkan peserta didik dalam pembelajaran.

Data aktivitas guru menunjukkan bahwa pada siklus I secara umum sudah baik, namun ada beberapa komponen penilaian dari observer yang masih kurang yaitu penggunaan media pembelajaran belum optimal, penguasan materi masih perlu ditingkatkan dan penggunaan bahasa yang masing dipotong-potong. Kekurangan-kekurangan pada siklus I ini kemudian diperbaiki pada siklus II dan aktivitas guru pada siklus II ini secara umum sudah baik.

Pembelajaran metode pemberian tugas ini dapat meningkatkan hasil belajar peserta didik karena pembelajaran dengan menggunakan metode pembelajaran tugas peserta didik dalam pembelajaran menjadi lebih aktif, kreatif, dan menyenangkan bagi peserta didik. Selain itu pula pembelajaran dengan metode pemberian tugas menjadi lebih efektif. Akibatnya informasi yang diterima peserta didik akan diingat lebih lama.

Peningkatan hasil belajar yang signifikan antara sebelum dan sesudah belajar dengan menggunakan metode pemberian tugas karena dalam pembelajaran dengan menggunakan metode pemberian tugas, 
peserta didik merasa tidak belajar karena pembelajarannya menyenangkan bagi mereka. Hal tersebut membuat pelajaran menjadi melekat lebih lama dan baik secara langsung maupun tidak langsung, membuat peserta didik menjadi paham mata Pelajaran Matematika tentang dimensi tiga.

\section{Kesimpulan}

Berdasarkan hasil penelitian yang telah dilakukan tentang dimensi tiga, bahwa hasil belajar peserta didik sesudah menggunakan metode pemberian tugas menunjukkan hasil yang memuaskan. Dari uraian pada bab sebelumnya, dapat diambil simpulan sebagai berikut:

1. Adanya peningkatan hasil belajar peserta didik pada mata Pelajaran Matematika tentang dimensi tiga di kelas XII IPA 1 SMA Negeri 1 Bojonggede Kabupaten Bogor dengan metode pemberian tugas.

2. Penggunaan metode pemberian tugas dalam pembelajaran membuat peserta didik tidak bosan dan jenuh sebaliknya merasa senang sehingga aktivitas belajar mereka meningkat. Hal ini terbukti data mengenai aktifitas peserta didik pada siklus I menunjukkan bahwa jumlah skor peserta didik 77 $(61,11 \%)$ dalam kerjasama dengan teman, sedangkan nilai keaktifan dalam kelompok skornya 79 atau $(62,69 \%)$. Kemudian peserta didik dalam aktif bertanya skornya 74 atau $(58,73 \%)$. Adapun peserta didik yang mengerjakan tugas guru skornya 96 atau (76,69\%), pada data mengenai aktifitas peserta didik pada siklus II menunjukkan bahwa jumlah skor peserta didik 119 (94,44\%) dalam kerjasama dengan teman, sedangkan nilai keaktifan dalam kelompok skornya 117 atau $(92,86 \%)$. Kemudian peserta didik dalam aktif bertanya skornya 107 atau $(84,92 \%)$. Adapun peserta didik yang mengerjakan tugas guru skornya 126 atau (100\%).

3. Hasil belajar mata Pelajaran Matematika khususnya tentang dimensi tiga di kelas XII IPA 1 di SMA Negeri 1 Bojonggede Kabupaten Bogor sebelum menggunakan metode pemberian tugas mempunyai nilai rata-rata 60,71. Pada saat pembelajaran diubah menggunakan metode pemberian tugas, rata-rata hasil belajar peserta didik meningkat menjadi 70,36 pada siklus I dan 78,81 pada siklus II.

\section{Ucapan Terima Kasih}

Segala puji syukur peneliti panjatkan ke hadirat Tuhan Yang Maha Esa atas berkat dan rahmat-Nya yang telah melindungi dan membimbing sehingga penulis dapat menyelesaikan penyusunan penelitian ini yang berjudul "Penerapan Metode Tugas Guna Meningkatkan Hasil Belajar Tentang Dimensi Tiga Di SMA Negeri 1 Bojong Gede - Kabupaten Bogor". Penulis dengan segala kerendahan hati, dalam kesempatan ini penulis ingin mengucapkan terima kasih kepada berbagai pihak di SMA Negeri 1 Bojong Gede - Kabupaten Bogor, sehingga penelitian ini tidak akan terlaksana tanpa bantuan dan dukungan dari kepala sekolah, guru, dan peserta didik di kelas XII IPA SMA Negeri 1 Bojong Gede Kabupaten Bogor. 
Edu Cendikia: Jurnal Ilmiah Kependidikan

Volume: 1 | Nomor 3 | Desember 2021 | E-ISSN: 2798-365X | DOI: 10.47709/educendikia.v1i3.1187

\section{Referensi}

Aisyah, N. (2007). Pengembangan Pembelajaran Matematika. Jakarta: Dirjen DiktiDepdiknas.

Alhamidi, Lubban Anwari and Ariwibowo, Prasetio and Djuhartono, Tjipto (2021) Effectiveness of Double System Education Programs in Education Curriculum Performance Vocational High School. In: ICOPE 2020, 16-17 October 2020, Universitas Lampung, Bandar Lampung, Indonesia.

Djaelani, M. S, dkk. (2015). Dasar-Dasar Kependidikan. Tanggerang: PT. Pustaka Mandiri.

Dr. Ellis Mardiana Panggabean, M.Pd (2020), Geometri Analitik Ruang, Medan:Pustaka Pemuda Ermawan, Y. F. (2017). Penanaman Konsep Life Long Education pada Siswa. Jurnal Tunas Bangsa. ISSN: 2355-0066.

Hasil Belajar Sains pada Siswa No. 2 Sikara Kecamatan SindueTobata. Jurnal Kreatif Tadulako Online, Vol. 4 No 8, ISSN: 2354-614X.

Hendarto Cahyono (2019), Geometri Analitik Bidang, Yogyakarta:UMM PRESS

Hidayat, S dan Tjitrosoemarto, S. (2017). Perencanaan Pendidikan. Tanggerang: PT.Pustaka Mandiri.

Hidayat, S. (2015). Penelitian Tindakan Kelas (PTK). Tanggerang: PT. Pustaka Mandiri.

Hidayat, S. (2015). Teori dan Prinsip Pendidikan. Tanggerang: PT. Pustaka Mandiri.

Hidayat, S. (2019). Teori, Proses, dan Konteks Sosial Budaya Pendidikan.Tanggerang: PT. Pustaka Mandiri.

Ibnu Ngathoillah (2018), Geometri Tiga Dimensi, Tangerang: Rajawali Press

Jurnal Dimensi Matematika, https://doi.org/10.33059/jdm.v3i01, published: 2020-06-02

Meningkatkan Hasil Belajar dan Kemampuan Berpikir Kreatif Siswa.Jurnal Pendidikan Matematika Indonesia 7, ISSN: 1693-1246.

Moedjiono dan Dimyati, M. (1992). Strategi Belajar Mengajar. Jakarta: Depdikbud.

Mustimah. (2014). Penerapan Pendekatan Keterampilan Proses untuk Meningkatkan

Qodir, A. (2017). Teori Belajar Humanistik Dalam Meningkatkan Prestasi Belajar Siswa. Jurnal Pedagogik, Vol. 04 No. 02 Jul-Des 2017, Print ISSN: 2345-7960, Online ISSN: 2528-5793.

Rahayu, E, dkk. (2011). Pembelajaran Sains dengan Pendekatan KeterampilanProses untuk Suprihatiningrum, J.(2014). Strategi Pembelajaran Teori dan Aplikasinya. Yogyakarta:Ar-Ruzz Media.

Zalyana. (2016). Perbandingan Konsep Belajar, Strategi Pembelajaran dan Peran Guru (Perspektif Behaviorisme dan Konstruktivisme). Jurnal Al-hikmah, Vol. 13 No. 1 April 2016, ISSN: 1412-5382 